\title{
ICT in Education in Finland and Hong Kong. An Overview of the Present State of the Educational System at Various Levels
}

\author{
Päivi ATJONEN \\ Department of Education, Joensuu University \\ P.O.Box 111, FIN-80101 Joensuu, Finland \\ e-mail: paivi.atjonen@joensuu.fi
}

\section{Siu Cheung LI}

Department of Education Studies, Hong Kong Baptist University

Kowloon Tong, Kowloon, Hong Kong

e-mail: sandyli@hkbu.edu.hk

Received: May 2006

\begin{abstract}
This article gives a general framework for the understanding of the use of ICT in primary, secondary (vocational education excluded) and tertiary education in both Finland and Hong Kong. We describe the quantity and quality of ICT infrastructure and teachers' skills and attitudes towards it. Based on various surveys and scientific research, the pedagogical use of ICT is also studied from the pupils' and teachers' viewpoint. There is also some discussion on developmental challenges.
\end{abstract}

Key words: information and communication technology, Finland, Hong Kong.

\section{General Geographical and Educational Contexts}

Finland in Europe, and Hong Kong Special Administrative Region (HKSAR, hereafter Hong Kong in this article) in China, have many geographical, cultural and system-wide differences which may have an effect on the framing and implementation of ICT in education. Finland has 5.2 million and Hong Kong 6.8 million inhabitants, but the crucial difference lies in the size of areas: Finland is $338000 \mathrm{~km}^{2}$ and Hong Kong $1098 \mathrm{~km}^{2}$. For example, distance education is on a very different scale, and sizes of schools vary a lot.

In Finland in 2003 (Statistics Finland, 2006a), there were about 4200 schools, 52000 teachers and 700000 pupils in primary and secondary schools (pupils' age either 7-12 or 12-16 years). Vocational education as a part of secondary education is not described in this article. In Hong Kong in 2004-2005, there were about 1350 schools, comprising of public schools, private schools, special schools, and international schools. Altogether these recruited about 50000 school teachers and provided places for about 890000 pupils with their age ranging from 6-12 at the primary level and 12-17 at the secondary level (HKSAR, 2005). 
In tertiary education, Finland has 20 universities (all are state universities) and in 2005 there was a teaching staff of about 7600 persons and student numbering of 176600 (KOTA, 2006). In Hong Kong, there are 12 higher education institutions which award degrees, eight of these are publicly funded by the government. At present, 14500 firstyear, first-degree places, are funded by the government, covering about 18 per cent of the 17-20 age group. In the eight government-funded tertiary institutes, there are about 5 325 academic staff members and 69300 full-time equivalent students (UGC, 2005). Note should be taken that the student number given here did not reflect the number of students enrolled in self-funded programmes offered by various institutes.

Considering the large number of teachers and pupils in question in both Finland and Hong Kong, it is not easy to implement any innovations into primary and secondary education. This is also true in the case of promoting the use of ICT in education. Teachers' ICT skills, attitudes, age and general competence vary a lot, and pupils have different ICT backgrounds. The situation in the university sector is perhaps in better shape, as far as the use of advanced educational-pedagogical technology is concerned, although there is a constant need for establishing and updating ICT skills of professors, lecturers and assistants.

Despite the many geographical and cultural differences, a lot can be found in common between Finland and Hong Kong concerning their educational efforts. Many universities in Finland and Hong Kong (such as University of Joensuu and Hong Kong Baptist University) have student/teacher exchange, research programmes and contracts. Both countries have participated in the same international evaluations (e.g., PISA, Program for International Student Assessment) to order to clarify the national differences and similarities (OECD 2003). The technological infrastructure is well established and developed in both areas, and efforts to promote the use of technology as an important too in developing education are appreciated.

\section{Main Strategic Plans for Developing ICT}

Two strategic plans have been launched by the Ministry of Education in Finland during the last decade (in 1995 and 1999). The third and the latest "Information society programme for education, training and research 2004-2006" (Ministry of Education, 2004) was published in 2004, which included primary, secondary and tertiary education in the same policy. The activities fall into three categories, 'knowledge', 'content' and 'the operating environment'. The programme is geared to

- develop all citizens' information society knowledge and skills,

- enable educational institutions to use ICT in a versatile way in their activities,

- establish ICT-based procedures in education, training and research,

- promote social innovation through the use of ICT.

While having no centralized policy on advancing the use of IT in tertiary education, the Education and Manpower Bureau of HKSAR Government has launched two important strategic plans: "Information Technology for Learning in a New Era" and "Empowering 
Learning and Teaching with Information Technology" which are designed to promote ICT in education in the school sector in 1998 and 2004 respectively. Embarking upon a student-centred approach, the new ICT in education initiatives were comprised of seven strategic goals, namely,

- empowering learners with ICT,

- empowering teachers with ICT,

- enhancing school leadership for the knowledge age,

- enriching digital resources for learning,

- improving ICT infrastructure and pioneering pedagogy using ICT,

- providing continuous research and development, and

- promoting community-wide support and community building.

Because of the different perspectives of the documents, it is difficult to find concrete similarities in the ICT policies between Finland and Hong Kong. However closer look at the Finnish programme reveals that the main aims at schools', teachers' and pupils' level (such as in-service education, e-learning materials, digital/information literacy, technicalpedagogical support) are very much the same as in Hong Kong. Recommendations or demands for the implementation of the programmes vary in the two regions, due to the different administrative-educational structures and procedures.

Both Hong Kong and Finland have assessed that there have been obvious advancements towards the aims and objectives of the strategy documents but hard developmental efforts are still needed in the future.

\section{Technical Infrastructure of ICT}

In Finland all primary and secondary schools are connected to the Internet and $81 \%$ of the connections are based on the broadband technology (Immonen-Oikkonen, 2005; Koivisto, 2005; Ministry of Education, 2005, p. 16). All university computers are connected to the Internet. In the primary and secondary education, the average number of pupils per workstation is six, which is in accordance with the average level in the international context too (OECD, 2005, p. 27).

About two thirds of workstations in primary and secondary education are multimedia computers, and in practice, all university computers are the same as well. CDROM drives, laser printers and scanners are the most typical peripherals in primary and secondary education. Based on their circumstances there is a huge variation between the build-up in different schools: for example, rural schools with only 20 pupils, and metropolitan schools with 400 pupils, struggle with different ICT needs. The real challenge as such, is the large number of schools: how to reach all the schools both mentally and technically and to involve them in the task of promoting the pedagogical use of ICT?

Hong Kong has, like Finland, invested substantially in improving the technical infrastructure of ICT at schools or universities. At the tertiary level, all computers have broadband Internet access. Recently, universities have been experimenting on the use of Internet in enhancing the performance of the existing network infrastructure. At the 
school level, the statistics derived from the overall study on reviewing and evaluating the progress of the "Information Technology in Education (ITEd) Projects 1998/2003" conducted during 2002-2004 (EMB, 2005) indicated, that the student to computer ratios were about 7.4, 4.6 and 2 students per computer in the Primary, Secondary and Special School sectors respectively. While in 2005 all schools reported that they were connected to the Internet, $95.8 \%$ (primary schools), $97.6 \%$ (secondary schools) and $93.9 \%$ (special schools) used broadband.

To remove the physical barrier of learning in the classroom and to promote the elearning culture, the Education and Manpower Bureau (EMB) has recently provided enhancement grants to support schools in implementing a wireless LAN with access points, to supplement the existing wired LAN in school.

Owing to the densely populated, relatively small geographical area, schools in Hong Kong are usually much bigger than those in Finland. One of the challenges for ICT implementation, is the lack of sufficient physical space for establishing an effective, technology-rich learning environment in school. The majority of computers are located in special rooms rather than in classrooms which affect the teachers' use of ICT in teaching and learning.

Both in Hong Kong and Finland, the teachers' main complaint about the infrastructure concerns the small number of workstations, although development since SITES (the Second Information Technology in Education Study 1998-1999) is obvious in both areas (Kankaanranta et al., 2000). Subject-based software is also equally desired. Not only the amount of equipment and software but also keeping it up to date, causes an endless, money-consuming race. All this may have remarkable effects on pedagogy.

\section{The Use of ICT from the Teachers' Viewpoint}

\section{Primary and Secondary Education}

According to various Finnish surveys and investigations, teachers have fairly positive attitudes towards the use of computers in the classrooms. They have gradually increased their ICT skills so that following private use (planning teaching, writing tests and assessment forms, using email) they have gained the courage to experiment with computers in the classroom situation too. Teachers have been most familiar with data processors, www, subject-based computer programs (incl. CD-ROMs) and email (Sinko and Lehtinen, 1999; Ilomäki, 2002; Atjonen, 2005). In these respects, Finland is a very typical European country (Hernes et al., 2005; Higgins, 2005; Hylén, 2003) however there have also been reports of many innovative experiments (Kankaanranta, 2005).

Pupils have sometimes seen their teachers' skills as being inadequate, and many teachers report that they need continuous in-service education and technical support at schools. The objective of teachers' in-service education, is that by the year $2007,75 \%$ of teachers would reach the level II (= fluent and versatile use of ICT, good pedagogic skills) which means that altogether they have $5+5$ credits from ICT-related studies (Ministry of 
Education, 2004, p. 14; Insight 2005, p. 86). The highest level III means having special skills including the mentoring of other teachers which requires five additional study credits. The job of in-service education is hard: the annual aim is to educate 1600 teachers (Koivisto, 2005). Due to teachers' heterogeneous age and educational background, a remarkable variety in their skills and everyday ICT activities can be observed at schools.

By the end of the 2002-2003 school year, all teachers (about 50600 including 4600 teaching assistants) in Hong Kong had completed ICT training at the Basic Level. About $35600(77 \%)$ teachers are at the Intermediate Level, 12500 (27\%) teachers at the Upper Intermediate Level and $2600(6 \%)$ teachers at the Advanced Level. In contrast, the survey on teachers' self-perceptions of their competence (EMB, 2005) revealed that $10.3 \%$ of teachers claimed that they could use ICT creatively and effectively for teaching and learning, 38.8\% of them indicated that they were competent in using ICT to assist teaching, $24.5 \%$ of them pointed out that they were comfortable and confident in using ICT to accomplish certain tasks, and about $26 \%$ of them claimed themselves to be starters or novice users. It is apparent that there was significant disparity between teachers' competency levels as reported, and teachers' self perceptions of their proficiency in using ICT in teaching and learning. Some teachers commented that most of the training programmes were technologically rather than pedagogically oriented, and thus unable to address their needs; similar opinions have been heard from Finnish teachers as well.

Regarding the usage of ICT, teachers reported in the EMB 2005 survey, that the software tools they often used in teaching were word processors (96.4\%), spreadsheets (79.3\%), presentation software (77.8\%), and communication software (73\%). Over 90\% (as compared to $76 \%$ in 2001) of the teachers indicated that they use ICT for preparing teaching material as well as searching for information and new pedagogies. These figures indicated that ICT is becoming an integral part of teachers' daily practice.

Although obvious progress has been made during the last ten years, and the level of 'good average' on the international scale of comparison has been achieved, Finland and Hong Kong still have a lot of work ahead. In both regions there are many advanced teachers who have innovatively adopted various practices of e-Learning, m-Learning and u-Learning (electronic, mobile, ubiquitous).

Teachers' in-service education is important, not only in technical issues but also pedagogically, because ICT is expected to be a factor in both promoting and exploiting pupilcentred teaching and learning methods. Various international research (e.g., Hylén, 2003; Nordic countries, 2006; OECD, 2005; Smeets and Mooij, 2001) indicates that it is not only the amount of equipment or software which is crucial, but the maximum use can be made of ICT only when teachers have fully realized the learner-centred pedagogy in practice.

\section{Universities}

The general, the ICT state of affairs in Finnish universities is good: technical infrastructure is at least satisfactory, and teaching staff has been quite active in improving its ICT skills through various in-service education channels. The constant aim of universities 
has been to provide students with the IT literacy that is necessary for their studies (use of e-library, statistical packages, word processors) and for their prospective professions (subject-specific software or equipment). Departments of teacher education (which belong to the universities in Finland) have prepared their own strategies for the pedagogical use of ICT and there have been attempts to put them into practice (Kähkönen, 2004; Nevgi and Tirri, 2003). Universities' ADP and educational technology centres have played an important part in promoting technological infrastructure and human resources.

Finnish universities have emphasized and enhanced the use of web-based courses in instruction (ordinary platforms: WebCT, Moodle). The consortium of the Finnish Virtual University (FVU) was established in January 2001. All 20 universities are members, and at the moment 42 different academic networks in several fields of study offer courses for university students (FVU, 2006a). For example, Helsinki University alone (the largest university in Finland) offered 1203 web-based courses in 2005 (FVU, 2006b). In addition to the FVU, all universities and their individual teachers have designed a multitude of web-based courses for university students and the students of open universities.

The Joint Universities Computer Centre (JUCC) in Hong Kong is a consortium of the eight government-funded tertiary institutes, responsible for coordinating information and communication technology services which are of mutual interest. JUCC is pro-active in promoting cross-institutional collaboration and innovatory projects, leading to the development and advancement of ICT facilities and services for the academic and research community in Hong Kong. In 2002, the consortium successfully connected the Hong Kong Academic and Research Network (HARNET) to the Internet. In this respect, the consortium has provided strong support in planning, managing and sustaining the development of the ICT infrastructure and facilities, both for teaching and learning, as well as for research activities in all local government-funded tertiary institutes.

To support web-based teaching and learning, the eight local tertiary institutes have their own course management systems (CMS) such as WebCT, Blackboard, etc. Some institutes have been pioneering the development of ubiquitous virtual learning environments such as VITLE, BUMoodle, Interactive Teachers' Network and the MindNet (Li, 2006) in order to improve collaborative learning and instruction delivery. In recent years, various universities have introduced a large number of self-funded master degree programmes, however these courses are mostly operated in the traditional face-to-face mode. A small number are operated in a hybrid mode (partly online and partly face-to-face), and only a few of them (excluding those offered by the Open University) are being delivered in a fully web-based mode.

To improve ICT practices, each individual institute has its own special unit or centre, catering for the provision of in-service professional development programmes for teaching staff. Likewise, information literacy programmes are provided by some universities for their undergraduate students, to ensure that they are able to reach the benchmark upon their graduation.

Considering both Finland and Hong Kong, comparable initiatives have been implemented to improve ICT practices and students' IT literacy. While there is a growing demand on web-based courses in both regions, the scale and momentum of the programme 
development vary. Such variation can perhaps be explained by the regional difference in geographic proximity between students and the education sources.

Although universities have made significant investments in building robust ICT infrastructure and facilities, the challenge continues to remain as to how to effectively integrate ICT in order to improve learning and to foster the new learning experience. Infrastructure, software applications and CMS by themselves, do not necessarily contribute to improving the learning experience. Members of faculties are duty bound to understand the prospects and performance of these tools and to use them accordingly in support of improved learning. To bring about a paradigmatic shift in practices, it is necessary to have an explicit institutional strategy for the installation of the ICT culture, and to facilitate the sharing of successful experience among faculty members.

\section{The Use of ICT from Students' Viewpoint}

\section{Primary and Secondary Education}

As in Hong Kong, surveys and investigations in Finland indicate that despite the fact that two households out of three have a computer (Statistics Finland, 2006c) the computer's appeal to pupils has not diminished even though it has been in the school curriculum for years. It became clear however, that Finnish pupils in the PISA 2003 had slightly more negative attitudes towards the use of ICT than, for example, Canadians, Germans or Koreans. Explanatory factors mentioned were gender, the availability of computers at home and the frequency of use (OECD, 2005, pp. 43-44).

According to the results of PISA 2003, almost 20\% of Finnish students said that they use computers at school almost every day or at least a few times per week. Finland was average in terms of pupils' self-assessed confidence in using routine ICT, Internet and high-level tasks (see also Statistics Finland, 2006b). Due to the general equality in Finnish society, the difference between males and females only slightly favoured males, however the gender difference was not as big as in many other European countries. PISA also indicated that half of the Finnish pupils had used computers for more than five years. Pupils without a computer at home did not perform as well as others in mathematics (OECD, 2005, p. 19, 23, 37, 47, 50, 55).

Students in Hong Kong generally welcomed the use of ICT by teachers (EMB, 2005). However, the extent to which it was popular decreased according to age. Some senior students expressed that their prime concern was lesson effectiveness rather than ICT merely being used as a means to arouse their interest.

The EMB survey results also indicate that the opportunity for using computers during lessons was limited. For instance, $67.9 \%$ of S4 (Grade 10) students mentioned that they had no chance of using computers during lessons at all. This reflects that the use of ICT in school was very much geared towards enhancing the teachers' role, while the emphasis on student empowerment in learning remained comparably weak. Despite these facts, test results on students' ICT proficiency indicate that students generally achieved the ICT learning targets stipulated by the government. 
In terms of ICT usage, the most common form, as reported by students, was for communication, collaboration with others such as in group projects, tackling practical problems in daily life and doing creative work.

Both in Hong Kong and Finland, researchers have been particularly interested in issues of open learning environment, access to and the management of diverse information, the pupils' active role and advantages of collaborative learning. Some pupils have become really advanced in ICT skills, and certain groups of boys in particular, have acquired the necessary generic skills which are demanded in an information society. The learning processes have really become more diversified and improved learning results are also evident.

There are still important challenges to be faced. One of those is sociological: How to give equal opportunities for the youngsters of poor families to develop their ICT skills, when we know that the advanced skills are mainly adopted outside the school curriculum? The other critical question is what do we exactly know about learning processes and results in the technology-rich learning environments?

\section{Universities}

Generally speaking, the support of student learning is very rich in Hong Kong due to the provision of ICT resources and facilities. These include fast networks, wireless connections, high performing computers, software packages for learning and research, e-books, e-journals, electronic databases and e-learning platforms etc. Some universities have incentive schemes to support students' purchase of notebook computers, PDAs, pocket PCs and other mobile devices. Core and elective subjects on the pedagogical use of ICT have been also incorporated in teacher education programmes. As stipulated in government policy (EMB, 1998), all pre-service teachers are required to have attained a certain level of ICT competency before entering the profession.

Various surveys and research concerning the university sector in Finland show that students are interested in web-based (distance) learning because it gives a more flexible framework for their studies in relation to time, place and choices of content. In teacher education in particular, student teachers attend some obligatory courses on the pedagogical use of ICT and test their knowledge while on teaching practice.

In the future, mobile technology and wireless connections open up new opportunities for the university sector (and also for any other levels of the educational system) both in Finland and in Hong Kong. Academic learning and research work are deeply intellectually embedded activities which pressurize and shape the development of ICT in many ways.

\section{Concluding Remarks}

Based on our comparative analysis of Finland and Hong Kong, it may be concluded that we share the main ups and downs of ICT in education. Regardless of various differences 
in both focus regions of this article, many key aspects of infrastructure, teachers' competence and students' motivation are similar to each other, and nothing very special can be said about Finland and Hong Kong in relation to the findings from international studies.

A good start has been made but constant work is ahead for both countries to update infrastructure and teachers' skills. Initial teacher education should also be under careful developmental consideration, because it gives the basic skills and prepares the way for positive attitudes. Some schools need support in the basic use of ICT, and others require specified consultation in using highly advanced technology (like mobile and wireless technology). Problems of heterogeneity should be tackled constructively.

Researchers are faced with the challenge of focusing even more intensively than earlier on the impact of ICT on pedagogical processes and learning results. New research methodologies are also needed to explore pedagogical applications of ICT. Culturalcontextual aspects have also been neglected: the western way for example of producing and developing educational software, is not valid for developing countries and to IT users of various ethnical backgrounds. Results of reliable, valid scientific studies are not too numerous and too much is based on hopes and beliefs. Detailed information is needed for the education of teachers and the preparation of digital learning material.

\section{References}

Atjonen, P. (2005). Tieto- ja viestintätekniikka yleissivistävän koulun pedagogisena haasteena (in Finnish, Educational technology as a pedagogical challenge for comprehensive schools). Joensuun yliopisto. Kasvatustieteiden tiedekunnan tutkimuksia 95.

EMB (1998). Information Technology for Learning in a New Era. Five-Year Strategy 1998/99 to 2002/03. http://www.emb.gov.hk/FileManager/EN/Content_2309/five\%20year\%20strategy 2099\%20to2003. zip (assessed 28 April 2006).

EMB (2005). Overall Study on Reviewing the Progress and Evaluating the Information Technology in Education (ITEd) Projects 1998/2003.

http: / / www.emb.gov.hk/index.aspx? langno=1\&nodeID=4 411 (assessed 28 April 2006).

FVU (2006a). Hankkeet ja yhdyshenkilöt (in Finnish, Projects and their Contact Persons).

http://www.virtuaaliyliopisto.fi/?node=vy_tietoa_svy_toimijat_hank_fin (assessed 5 April 2006).

FVU (2006b). SVY-toiminnan tärkeimmät mittarit ja tunnusluvut yliopistoittain (in Finnish, Main Instruments and Key Figures of the Activities of the FVU).

http://www.virtuaaliyliopisto.fi/?node=vp_svy_toiminnan_mittarit_fin (assessed 5 April 2006).

Hernes, F., M. Hestman and E. Haaland (2005). Knowledge and Competence in ICT among Teachers in Norway. Norwegian university of science and technology.

http://www.ifip.or.at/con2000/iceut2000/iceut09-04.pdf, 283-288 (assessed 21 March 2006).

Higgins, S. (2005). Does ICT Improve Learning and Teaching in Schools? A professional user review of UK research undertaken for the British Educational Research Association. Newcastle University. http: / / www . bera. ac.uk/publications/pdfs/ICT\%20PUR 20 MB $\% 20 r-f-$ p $\% 201$ Aug 03 .pdf (assessed 22 February 2006).

HKSAR (2005). Hong Kong Special Administrative Region Yearbook 2004.

http: //www.info.gov.hk/yearbook/2004/en/07_04.htm (assessed 28 April 2006).

Hylén, J. (2003). ICT in the School. An International Comparison from a Swedish Perspective. http://www.kollegiet.com/documents/pdf/KK_rapport_IT_eng.pdf (assessed 21 February 2006). 
Ilomäki, L. (Ed.) (2002). Tietotekniikka koulun arjessa. Loppuraportti Helsingin kaupungin opetustoimen tietotekniikkaprojektista 1996-2000 (in Finnish, Information Technology in Workdays of Schools. Final report on the project of information technology in Helsinki City from 1996 to 2000). Helsingin kaupungin opetusviraston julkaisusarja A2.

Immonen-Oikkonen, P. (2005). ICT in Special Needs Education. Finnish National Board of Education. http: //www.oph.fi/info/finlandinpisastudies/conference2005/koivisto.ppt (assessed 7 April 2006).

Insight (2005). Assessment Schemes for Teachers' ICT Competence - A Policy Analysis. Results from PIC/P2P Survey.

http://www.eun.org/insight-pdf/special_reports/PIC_Report_Assessment 20schemes_insightn.pdf (assessed 7 April 2006).

Kankaanranta, M. (2005). Innovative Pedagogical Practices in Technology-Enhanced Education - Finnish Perspective.

http://e.finland.fi/netcomm/news/showarticle.asp?intNWSAID=41844 (assessed 7 April 2006).

Kankaanranta, M., E. Puhakka and P. Linnakylä (2000). Tietotekniikka koulussa. Kansainvälisen arvioinnin tuloksia (in Finnish, Information Technology at Schools. Results on the international assessment. The IEA second information technology in education study SITES). Koulutuksen tutkimuslaitos, Jyväskylä.

Koivisto, J. (2005). ICT in Learning in Finland. Finnish National Board of Education. http: //www.oph.fi/info/finlandinpisastudies/conference2005/koivisto.ppt (assessed 7 April 2006).

KOTA (2006). An Online Database of Finnish Universities. http://kotaplus.csc.fi:7777/online/Etusivu.do (assessed 5 April 2006).

Kähkönen, E. (Ed.) (2004). Verkko-oppimisen vakiintuessa. Näkökulmia ja arvioita mielekkyydestä, rahasta ja strategioista (in Finnish, When Virtual Learning is Becoming Stable. Perspectives of and Assessments on Meaningfulness, Money and Strategies). Itä-Suomen virtuaaliyliopisto, Joensuu.

Li, S.C. (2006). A constructivist approach to designing computer supported concept mapping environment. International Journal of Instructional Media, 33(2) (in press).

Ministry of Education (2004). Information Society Programme for Education, Training and Research 2004 2006.

http: //www.minedu.fi/julkaisut/koulutus/2004/opm14/opm14.pdf (assessed 3 April 2006).

Ministry of Education (2005). Tietoyhteiskunnan rakenteet oppilaitoksissa - vuoden 2004 kartoitusten tulokset ja vuosien 2000-2004 yhteenveto (in Finnish, Information Society Structures in Educational Institutions Results of the Surveys 2004 and Summary of the Years 2000-2004).

http://www.minedu.fi/opm/koulutus/pdf/Tietoyhtkunnan_rakenteet.pdf (assessed 7 April 2006).

Nevgi, A., and K. Tirri (2003). Hyvää verkko-opetusta etsimässä (in Finnish, In Search of Good Virtual Teaching). Suomen kasvatustieteellinen seura. Kasvatusalan tutkimuksia 15.

Nordic countries (2006). E-learning Nordic 2006. Impact of ICT on Education. http://www.edu.fi/julkaisut/eLearning_Nordic_English.pdf (assessed 8 May 2006). OECD (2003). Learning for Tomorrow's World. First Results from 2003. http: //www.pisa.oecd.org/dataoecd/1/60/34002216.pdf (assessed 7 April 2006).

OECD (2005). Are Students Ready for a Technology-Rich World? What PISA Studies Tell us. http: //www.pisa. oecd.org/dataoecd/28/4/35995145.pdf (assessed 4 April 2006).

Sinko, M., and E. Lehtinen (1999). Challenges of ICT in Finnish Education. http: / / www.sitra.fi/Julkaisut/sitra227.pdf (assessed 3 April 2006).

Smeets, E., and T. Mooij (2001). Pupil-centred learning, ICT and teacher behaviour: Observations in educational practice. British Journal of Educational Technology, 32(4), 403-417.

Statistics Finland (2006a). Opettajien määrä lähes edellisvuoden tasolla (in Finnish, Number of Teachers is Almost the Same as the Year Before).

http://www.stat.fi/til/ope/2003/ope_2003_2005-05-03_tie_001.html (assessed 5 April 2006).

Statistics Finland (2006b). Tietokoneen ja tietoverkon koulukäyttö (in Finnish, Use of Computers and Networks at Schools). http://www.stat.fi/tk/yr/tietoyhteiskunta/koulu.html\#kaytto 
(assessed 6 April 2006)

Statistics Finland (2006c). Tietotekniikasta tullut osa suomalaisten arkipäivää (in Finnish, Information Technology has Become a Part of Finns' Weekdays, Statistics Finland).

http://www.stat.fi/ajk/tiedotteet/v2006/tiedote_017_2006-03-08.html (assessed 6 April 2006).

UGC (2004). University Grant Committee. Student Enrolment (Full-Time Equivalent) of UGC-Funded Programmes by Institution and Level of Study, 1998/99 to 2004/05.

http: / / www.ugc.edu.hk/eng/ugc/publication/report/figure2004/images

/figure_pdf/figure3.pdf (assessed 28 April 2006).

P. Atjonen first worked at the University of Oulu (Kajaani Department of Teacher Education) and now works as professor of education at the University of Joensuu. She is also a docent of pedagogy at the University of Helsinki, a member of the Finnish Education Evaluation Council and the chair of the Editorial Board of Kasvatus (a peer-reviewed Finnish journal on educational sciences). She has published more than 150 books, scientific reports and articles on curriculum development, teachers' pedagogical thinking, pedagogical ethics, and information and communication technology.

S.C. Li received a BSc (Hons) in 1984 from the University of Hong Kong and postgraduate certificate in education in subsequent years from the same university. He received his $\mathrm{PhD}$ in theoretical nuclear and particle physics in 1996 from the Australian National University. He was a secondary school teacher in Hong Kong for eight years before pursuing his $\mathrm{PhD}$ degree. He was a postdoctoral research fellow in ANU, working in the area of computer simulation and modelling of protein dynamics. He subsequently joined the Centre for Information Technology in Education of the Faculty of Education of the University of Hong Kong as the deputy director from 1998-2001. He is currently an associate professor and also the course coordinator of the full-time postgraduate diploma in education programme of Department of Education Studies at Hong Kong Baptist Unuversity. He has been the principal investigator of a number of research projects in the area of IT in education, funded by the Competitive Earmarked Research Grant Committee and the HKSAR government. 


\title{
Informacinès ir komunikacinės technologijos Suomijos ir Honkongo švietime
}

\author{
Päivi ATJONEN, Siu Cheung LI
}

Straipsnyje supažindinama su informaciniu ir komunikacinių technologiju (IKT) naudojimu Suomijos ir Honkongo pradiniam, viduriniam (iskaitant ir profesinį mokymą) ir aukštajam mokymui. Aprašoma su IKT susijusių abiejų šalių infrastruktūrų, mokytojų igūdžių bei požiūrių kokybè ir kiekybė. Straipsnyje, remiantis įvairiomis apklausomis ir tyrimais, nagrinejjami ir mokytoju (dèstytoju), ir mokiniu (studentu) požiūriai ị pedagoginę IKT naudą švietimui. Taip pat kreipiamas dèmesys į IKT keliamus naujus tikslus, uždavinius, iššūkius moderniai plètrai. 